\title{
Reflecting on Green Infrastructure and Spatial Planning in Africa: The Complexities, Perceptions, and Way Forward
}

\author{
Elizelle Juaneé Cilliers@
}

Unit for Environmental Sciences and Management, North-West University, Private Bag X6001, Potchefstroom 2520, South Africa; juanee.cilliers@nwu.ac.za

Received: 13 December 2018; Accepted: 3 January 2019; Published: 16 January 2019

\begin{abstract}
Spatial planning decision-making is progressively acknowledging that nature-based solutions are substantially beneficial to urban communities and their host cities. This paper is a meta-study of the current state of spatial planning practice in South Africa, with special focus on nature-based solutions and green infrastructure planning. The complexities and perceptions relating to green infrastructure planning in South Africa is presented, based on the findings of nine independent studies conducted between 2014 and 2018. The collective interpretation of these findings are thematically reported on in terms of (i) the concept of Green Infrastructure as perceived from a local perspective, ii2) the functionality of green infrastructure in local (urban and rural) context, (iii) the benefits (and value) of green infrastructure in local context which probe to be contradicting international accepted theory, and (iv) long term planning strategies and opportunities relating to green infrastructure provision in South Africa and Africa. The paper emphasizes the importance of context-based planning based on the unique considerations illustrated in the (South) African case studies which amongst others disproved the green compensation hypothesis and disproved the green proximity principle. As a result, the paper calls on long-term strategies to align green infrastructure as part of mainstream spatial planning approaches, along with value capturing approaches to sensitize decision-makers to prioritize green infrastructure within broader land-use planning approaches.
\end{abstract}

Keywords: green infrastructure; value-capturing; context-based planning; African approaches

\section{Introduction}

Land was once plenteous and resources were abundant. The 21st century depicts a different picture as increased populations, urbanization, and climate change challenges brought along uncontrolled and unsustainable practices. Land was once considered a local issue, but is now recognized as a force of global importance in the quest to balance the Earth's regenerative capacity and the increasing human demands [1,2]. Sustainability manifested as a universal ambition, also imbedded in global spatial planning approaches aligned to the United Nations Sustainable Development Goals, calling for amongst others, inclusive, safe, resilient and sustainable cities and human settlements [3]. The spatial approach towards sustainability now recognizes the interrelated role of the environment and the unique ecology within cities as catalyst to realizing objectives of sustainability [4].

As a result, environmental considerations have become an integral part of international spatial planning approaches and decision-making, to a point where there is now an expanded scientific understanding that nature-based solutions are substantially beneficial to urban communities and cities [5-7], and that ecological principles are a sine qua non for effective designs and sustainable cities $[2,8-10]$. The academic discourse on urban sustainability $[2,11,12]$ introduced the notion of green infrastructure as a nature-based solution to complex urban problems, contextualizing green 
infrastructure as "spatially and functionally integrated systems in aid of sustainability" [13]. Within this understanding, green infrastructure is defined as "society's natural life system" [14,15].

Various studies were conducted to present the state of green infrastructure globally, referring to the concept and the interpretation thereof within broader planning approaches $[14,16,17]$. From a spatial planning perspective, it was evident that the concept of green infrastructure enhanced the understanding that green assets and ecological systems function as part of the infrastructural fabric that supports and sustains society and builds resilience [18] and secures the provisioning of ecosystem services in human-dominated city landscapes [19]. It is considered 'infrastructure' through its ability to deliver goods and services [20] and should therefore be planned as an integral part of a city's infrastructure and green network, and not approached as ad hoc urban greening projects. Green infrastructure as a 'public good' [21] is articulated in terms of its ecological values, social values, and economic values that conveys to communities and their host cities [22-25].

These values are extensively quantified in literature [26], with various studies translating the respective environmental, social, and economic values to reflect the financial price of green infrastructure, by using methods relating to willingness-to-pay, travel costs, direct monetary damages, the household production approach, or some combination of these [27]. Other methodologies focus on the impact of green infrastructure on properties and neighborhood valuations [28] and incorporate the amenity value of green spaces [29]. These studies confirm the proximity principle and illustrate the importance of proximity to natural areas in terms of increased residential land prices [30]. Other studies reflect on the compensation hypothesis, as a relatively rudimentary concept, which state that citizens will compensate poor access, or, reduced area of private green space, for access to public green space [31] within a broader green infrastructure network. Compensation theories, in this sense, is often influenced by the functionality of green infrastructure (or the lack thereof), in terms of accessibility [32,33], connectivity [34,35], and scale [32,35]. The myriad of literature reporting on the value of Green Infrastructure provides a clear distinction between benefits for communities (neighborhood-scale) and benefits pertaining to cities (city-scale) [26], but stresses the importance of multi-functionality [17] across scales and users, as a core principle of green infrastructure [7].

The overall findings of research pertaining to green infrastructure kindles the realization of the importance of green infrastructure as a core dominator towards sustainable development and calls upon a long-term vision to inform the spatial planning reality. However, most of the literature on green infrastructure relates to research conducted in developed countries [26], where the social and cultural context, as well as spatial challenges (high levels of poverty, lack of access to basic services, housing backlogs etc. [26]) are widely divergent from those in developing countries. As a result, more scholars are now probing for expanded considerations and context-based research relating to green infrastructure. The (South) African approach to planning green infrastructure could contribute to the academic discourse to shed light on reasons why the African urban landscape fails to emulate Western models of urbanization [36] The complex web of political, social, economic, and environmental realities in the African context, brings a novel perspective to the planning of green infrastructure, understood from the point of departure where immense socio-economic issues and strained social contexts overshadow the need, and the understanding of the value of green infrastructure. The planning of green infrastructure should therefore be considered from a local context, acknowledging the possibility of different perceptions relating to the value and the importance of green infrastructure.

As a point of departure, this paper aimed to capture the status quo of planning practice in South Africa (and to a smaller extent Africa), based on a meta-study conducted on the concept, functionality, benefits, and long-term planning strategies relating to green infrastructure and the interpretation thereof in local context.

\section{Research Methods}

This paper presents an aggregation of research conducted over a five-year period, substantiated by nine individual studies. Researchers of the individual studies comprised of junior researchers 
(final year urban planning students as part of completion of the four-year professional Bachelor's degree), postgraduate students (Masters and PhD level), post-doctoral fellows and senior researchers (professors in urban and regional planning and urban ecology respectively). These studies, conducted between 2014 and 2018, reflected on different aspects pertaining to green infrastructure as applied in the local context, and were analyzed with IBMs SPSS software and interpreted collectively in this paper to conduce findings concerning the local interpretation of green infrastructure. The nine studies considered, along with specific methodologies (case study analysis, community analysis, and expert analysis) that informed the empirical findings of this paper are captured in Table 1.

Table 1. Selected studies and methodologies informing this research.

\begin{tabular}{|c|c|c|c|c|c|c|c|c|c|c|}
\hline & Focus & Author & Level * & Year & $N$ & 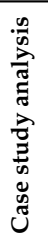 & 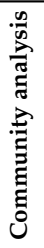 & 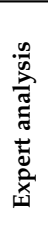 & Locality & Analysis \\
\hline 2 & $\begin{array}{l}\text { Proximity } \\
\text { principle }\end{array}$ & $\begin{array}{l}\text { Cilliers } \\
\text { Cilliers }\end{array}$ & 5 & 2015 & 188 & $x$ & & & $\begin{array}{l}\text { Potchefstroom, } \\
\text { North-West, SA }\end{array}$ & $\begin{array}{c}\text { Analysis of } \\
\text { variance (ANOVA) }\end{array}$ \\
\hline 3 & Green drivers & $\begin{array}{l}\text { Jacobs } \\
\text { Cilliers }\end{array}$ & $\begin{array}{l}2 \\
5\end{array}$ & 2016 & 30 & & $x$ & $x$ & $\begin{array}{c}\text { Klerksdorp, North-West, } \\
\text { SA }\end{array}$ & $\begin{array}{l}\text { Frequency of use, } \\
\text { descriptive statistics }\end{array}$ \\
\hline 6 & Green drivers & Cilliers & 5 & 2017 & 18 & & & $x$ & $\begin{array}{l}\text { SA, Lesotho, Sudan, } \\
\text { Nigeria, Mozambique }\end{array}$ & $\begin{array}{l}\text { Frequency of use, } \\
\text { descriptive statistics }\end{array}$ \\
\hline 7 & Green education & $\begin{array}{l}\text { Thysse } \\
\text { Cilliers }\end{array}$ & $\begin{array}{l}1 \\
5\end{array}$ & 2017 & 36 & & & $x$ & $\begin{array}{l}\text { South African } \\
\text { professionals }\end{array}$ & $\begin{array}{l}\text { Frequency of use, } \\
\text { descriptive statistics }\end{array}$ \\
\hline 8 & $\begin{array}{l}\text { Community } \\
\text { perceptions }\end{array}$ & $\begin{array}{l}\text { Louw } \\
\text { Cilliers }\end{array}$ & $\begin{array}{l}1 \\
5\end{array}$ & 2017 & 46 & & $x$ & & $\begin{array}{c}\text { Potchefstroom } \\
\text { urban/rural areas, SA }\end{array}$ & $\begin{array}{l}\text { Cramer's V-test and } \\
\text { cross- tabulations }\end{array}$ \\
\hline 9 & $\begin{array}{l}\text { Community } \\
\text { perceptions }\end{array}$ & $\begin{array}{l}\text { Gibbens } \\
\text { Cilliers }\end{array}$ & $\begin{array}{l}4 \\
5\end{array}$ & 2017 & 204 & & $x$ & & Griekwastad, SA & $\begin{array}{l}\text { Cramer's V-test and } \\
\text { cross-tabulations }\end{array}$ \\
\hline
\end{tabular}

Two studies comprised of a mixed method approach where both quantitative and qualitative methodologies were employed as part of a broader case study analysis (refer to number 2 and 5 above). These cases studies (Potchefstroom and Oudtshoorn) were considered from a spatial planning perspective, to reflect on theories relating to green space planning (proximity principle and the green compensation hypothesis) and the validity thereof in local context. Analysis of variance and Cramer's V-tests informed the results. Five studies (referring to numbers 1, 3, 5, 8, and 9) employed a community analysis by means of a structured questionnaire distributed to respective community members. Statistical analyses were based on Cramer's V-test, cross-tabulations and descriptive statistics to inform the results. Four studies (refer to numbers 3, 4, 6, and 7) employed an expert analysis where expert opinions related to green infrastructure where captured by means of a structured questionnaire distributed to a purposefully selected sample of professionals. Statistical analyses were again based on Cramer's V-test, cross-tabulations, and descriptive statistics. Cross tabulations were used to determine the association between variables within the specific studies where Cramer's V-test identified the effect size and practical significance thereof (in terms of large effect or practical significant association $\mathrm{V} \sim 0.5$; a medium effect or practical visible significant association $\mathrm{V} \sim 0.3$; and a small effect or practical non-significant association $\mathrm{V}$ 0.1) [37]. For purposes of this paper, the $p$-values are reported for completeness sake, but is not interpreted, since a convenience sample was used instead of a random sample. 


\section{Results}

The findings of the collective consideration of these nine studies were thematically structured, to inform on the (i) concept of green infrastructure as perceived from an (South) African perspective, specifically considering the notion and important role of green infrastructure and the perceptions towards community needs relating to green infrastructure, (ii) the functionality of green infrastructure in local context, considering the use of green spaces and green infrastructure in both urban and rural areas in South Africa, (iii) the benefits of green infrastructure specifically relating to the value connected to green infrastructure in the South African context, and (iv) long term planning strategies of green infrastructure provision in Africa and the perceived opportunities to strengthen green infrastructure planning approaches within the broader African context.

\subsection{Findings on the Notion of Green Infrastructure from a Local Perspective}

The green agenda is gaining importance within the African planning context, however, in comparison to international trends, Africa is still slow to plan for, and successfully implement green infrastructure as part of broader spatial planning approaches. Research conducted in 2016 [38] illustrated how South African Professional Planners utilized green infrastructure as part of spatial planning approaches, making specific reference to the frequency of use and successful implementation of green infrastructure in practice. Structured questionnaires were completed by purposefully selected participants, based on professional registration as urban planner at the South African Council for Planners (SACPLAN). The statistical analysis considered different levels of education, different provinces of employment, different sectors of employment and different levels of experience as professional planners. A total of $40 \%$ of the respondents working in the private sector, claimed to have never considered green infrastructure as part of spatial planning. All of the respondents employed in the public sector indicated to have considered green infrastructure as part of spatial planning before, making reference to policy and legislative frameworks that are moving towards integrated planning approaches. None of the other criteria employed in the statistical analysis (education levels or levels of experience) correlated with the frequency of use of green infrastructure. The only medium effect or practical visible significant association $(\mathrm{v}=0.439)$ was between the frequency of use of green infrastructure and the province in which participants were employed (Table 2). The research highlighted that adequate policies and legislative frameworks (applicable to specific provinces) could enhance the frequency of use of green infrastructure in the respective province of jurisdiction. However, green infrastructure is still very limited in planning practices in South Africa.

Table 2. Cross-tabulation: province of employment and frequency of green infrastructure use.

\begin{tabular}{cccccc}
\hline Cross Tabulation & $\begin{array}{c}\text { Question } \\
\text { Reference }\end{array}$ & $\begin{array}{c}\text { Number of } \\
\text { Valid Cases }(N)\end{array}$ & $\begin{array}{c}\text { Chi-Square } \\
\text { Test }\end{array}$ & $\begin{array}{c}\text { Cramer's } \\
\text { V-test Value }\end{array}$ & $\begin{array}{c}\text { Cramer's V-test } \\
\text { Approx. Sig. }\end{array}$ \\
\hline $\begin{array}{c}\text { Frequency of Green } \\
\text { Infrastructure use per } \\
\text { province }\end{array}$ & Q1 with Q12(a) & $39(97.5 \%)$ & 0.239 & 0.439 & 0.239 \\
\hline
\end{tabular}

In comparison to the international trends and academic discourse on green infrastructure, participants indicated that the local South African reality and practice is lacking behind in terms of implementation and realization of the vision for green infrastructure. Although green infrastructure is manifesting as a solution to various complex urban problems and being suggested by many professional planners and academics within the field, the implementation and realization thereof in a local South African context, is not considered successful. It was indicated by the participants that policies and legislative frameworks should be developed to align, and enforce the integration of green infrastructure as part of broader spatial planning approaches [38]. Such policies and legislative frameworks should be supported by guiding documents and training of planners, to equip planners with the adequate knowledge to sufficiently plan for green infrastructure. The lack of competence 
to plan sufficiently for green infrastructure was identified from two independent studies $[38,39]$ conducted among planning professionals in South Africa, where the lack of know-how and knowledge relating to green infrastructure was posed as reason for the limited implementation, as well as the uneven distribution of green infrastructure projects in practice.

The lack of budgets was also considered a further issue restricting the successful implementation of green infrastructure in South African context [26,38]. These findings conformed to the literature relating to green land uses and green infrastructure, that, similar to many other developing countries, has to continuously compete against other urban land uses [39], and are often not prioritized in the spatial planning process, due to limitations in budgets and human resources [40]. Upon further investigation it was evident that green infrastructure is often considered a luxury good within the broader African context, and not considered a necessity. Various stakeholders view green infrastructure as a visual attribute, not an economic good, and not as crucial in terms of spatial planning, in comparison to "more pressing needs" such as provision of basic services and housing [26].

This is especially true in the rural context, where budgets are mainly allocated for the provision of basic services and housing, and the provision of green spaces and green infrastructure does not deliver relief for such needs [41]. From the international definitions and conceptualization of green infrastructure, this is known to be untrue. Green infrastructure, as a necessity for sustainable community planning, does in fact provide a myriad of services to communities and authorities on different scales and levels [26]. Interestingly, despite socio-economic conditions being prioritized by planners as the core concern when planning for such deprived communities, the rural communities themselves emphasized their need for green spaces and their support towards green infrastructure networks. A community survey conducted in the rural area of Griekwastad in 2017, illustrated that $86.2 \%(n=58)$ of rural residents were not satisfied with the current open and green spaces in their neighborhood and $83.3 \%(n=59)$ considered such spaces insufficient for child play, as illustrated in Table 3.

Table 3. Descriptive statistics of perceptions regarding green spaces in rural areas.

\begin{tabular}{cccccc}
\hline $\begin{array}{c}\text { Respective } \\
\text { Green Space }\end{array}$ & $\boldsymbol{N}$ & Satisfied & Unsatisfied & Mean & Std. Deviation \\
\hline Sport fields & 58 & $13.8 \%$ & $86.2 \%$ & 3.21 & 0.811 \\
Play spaces & 59 & $16.7 \%$ & $83.3 \%$ & 3.24 & 0.858 \\
\hline
\end{tabular}

Rural community members in Griekwastad opted for budgets to be allocated to the development of green spaces and especially, child-friendly spaces, even at cost of the current budget allocated for basic services and infrastructure. The rural community members included in the survey emphasized (and prioritized) the need for children from rural areas to have well planned and maintained green spaces. Similar results, emphasizing the use-value of green spaces and green infrastructure were evident in the Fleurhof case study [42] where $62 \%$ of the respondents $(n=322)$ indicated that they would even be willing to pay more for areas with adequate green space and supporting green infrastructure. The research emphasized the importance to include communities in the planning process, to capture their actual needs and preferences. These cases emphasized that green spaces and broader green infrastructure networks should be prioritized in terms of land-use decision-making, and not be overshadowed by socio-economic conditions. The research highlighted the need to provide adequate green spaces and supporting green infrastructure in rural areas, especially since development opportunities, and recreational and socialization spaces are more limited in these areas, compared to their urban counterparts. The assumption was drawn that the role and value of green infrastructure should be contextualized, and formally defined within the (South) African environment, to enhance the planning and successful implementation thereof. Contextualizing green infrastructure in local context might change the false perception that green spaces are a luxury good, and strengthen the view that green infrastructure is a public amenity that benefits both the city, and its inhabitants. 
The lack of a sufficient definition and contextualization of green infrastructure within the South African planning context was identified in four independent studies [38,41,42]. Unanimously, all four studies identified the lack of definition as reason for misconceptions relating to green infrastructure, and motive why green spaces are more susceptible to land-use changes. This was also evident within the broader African context where a convenience sample of African professionals from Nigeria, Lesotho, Mozambique, Sudan and South Africa, all confirmed that green infrastructure is often not prioritized in the planning process, due to a lack of definition and misinterpretation of the role and importance thereof. The Consolidated Johannesburg Town Planning Scheme [43], for example, refers to open spaces as "property which is under the ownership of the Council or other public authority, with or without access control, and which is set aside for the public as an open space for recreation, games, sport or cultural activity". Open space, in this context, includes amongst others, green space, but does not define or contextualize green spaces or green infrastructure. In other African countries considered, the same trend was evident. An investigation into the understanding and definition of green infrastructure, as employed within an African context, revealed that no uniform understanding or definition of green infrastructure exists, or are included in spatial planning frameworks.

Research of Huston [38] furthermore illustrated that $69 \%$ of participants (from a purposefully selected sample of professional planners in South Africa) believe to understand what green infrastructure entails, but upon qualitative investigation, only $23 \%$ actually comprehended the concept. A similar trend was seen among local residents. Results from a detailed community survey conducted with 322 residents of the Fleurhof area in Johannesburg [42] illustrated that $93 \%$ of participants considered environmental planning to be important, but only 39\% showed a good understanding of the concept of green infrastructure. Statistical analysis identified that younger generations were more informed about green infrastructure with an effect size of 0.248 . Residents viewed green infrastructure not solely as a visual attribute, but also identified the functionality (use-value) of green infrastructure as an important issue.

The concept of green infrastructure from a South African (and broader African) perspective was concluded to be limited in comparison to the global perspective. Green infrastructure is not (yet) successfully implemented in practice due to various reasons of which the misconceptions relating to the important role and value of green infrastructure in terms of the economic, social, and environmental benefits are probably the core denominator. Green infrastructure is not fully integrated into the South African planning approaches and much work is needed to orientate stakeholders, communities, authorities, and planning professionals about the value and benefits of green infrastructure. Decision-makers need to be sensitized to prioritize green infrastructure within the land use and planning agendas. Green infrastructure should move from a luxury good to a necessity and life support system, integrated within broader Africa planning approaches. As point of departure, green infrastructure should be well defined within the African and global South context. Green assets and ecological systems should be emphasized to function as part of the infrastructural fabric that sustains society and builds resilience. The benefits and values (social, economic and environmental) of green infrastructure should be captured, quantified and interpreted from a local perspective, to build a stronger case for green infrastructure planning in Africa.

\subsection{Findings on Green Infrastructure Functionality in Local Context}

The functionality of green infrastructure in South Africa displayed a different scenario to that of the international environment, especially in terms of community usage of green spaces and green infrastructure. This research acknowledge that the contradicting results could be due to the misconceptions relating to green infrastructure in local context, and the undervaluation of such, as explained in the previous section, which could have a negative representation in terms of important green infrastructure principles such as accessibility, connectivity, and scale. The functionality of green infrastructure in South African context was investigated through the application of the compensation hypothesis, which departed from the understanding that communities with limited access to private 
green space will seek compensation elsewhere. The compensation theory was however disapproved for the South African case study included in this research, suggesting that the use of green infrastructure in South African context does not necessarily conform to that of the global norm.

The international accepted theory of green compensation $[44,45]$ was disproved for the South African case study of the rural surroundings of the town of Oudtshoorn in the West Cape Province of South Africa [31]. The green compensation hypothesis was considered as part of a case study analysis to investigate access to, and the use of green spaces in the low-income areas of Bridgton and Bongolethu townships, located within the greater Oudtshoorn region. The Bridgton and Bongolethu survey reached 101 households within the case study area. Respondent properties accommodated a total of 708 people, of which $510(72 \%)$ were housed in formal dwellings and $198(27.96 \%)$ called informal backyard rentals home. In total $53 \%$ of respondent properties accommodated informal backyard rental structures, with a total of 71 informal backyard dwellings recorded. The research area is in close proximity to an urban green space which was recently refurbishment. The refurbishment process was largely instigated in the hopes of providing a quality green recreational space within an impoverished community that could host events to draw people from all tiers of Oudtshoorn society [46]. 50.5\% of respondents claimed that they made increased use of the facility following its refurbishment, $27.7 \%$ claimed no change in regularity of use and $21.8 \%$ reported using the facility less than before. The majority of respondents $(65.3 \%)$ did not make routine use of proximate public green spaces, despite having limited access to private green space. $15.8 \%$ indicated they never used the public green spaces, whilst only $5 \%$ indicated that they used this green space on a daily basis. This survey thus disproved the compensation hypothesis, as it was evident that proximate public green spaces are used sporadically, and usage did not correlate to increased densities in the demarcated area. Compensation behaviors were not related to the number of dwellings [31]. Similar findings were evident in the Fleurhof case study in the Gauteng Province of South Africa [42] where stakeholders $(n=288)$ were reluctant to use the green spaces provided, irrespective of where the green spaces were located. In total $35 \%$ of residents indicated that they utilize these facilities less than once per year. Findings probe the need to reconsider urban and rural green space planning within low-cost areas, as well as accessibility to public green spaces, in relating to function and form [31]. Integrated planning which encapsulated multiple functions within a singular space could provide better results in terms of space usage and function, and should thus be considered in future research endeavors.

\subsection{Findings on Benefits of Green Infrastructure within Local Context}

Further to disapproving the green compensation theory, the green proximity principle was also disproved in a singular local case study. Five residential areas were selected in the North-West Province of Potchefstroom (South Africa), based on proximity to green space and was a refinement of previous research [47]. The respective case study areas and location of urban green spaces are illustrated in Figure 1 by the $\left.{ }^{*}\right)$ in relation to the Central Business District (CBD).

Selected green spaces were zoned as public spaces and accessible to all communities. All of these spaces were under jurisdiction of the local authority (now known as JB Marks Local Municipality) and subject to maintenance from said authority, except for the green space in Grimbeek Park, that was privately maintained. In each of the areas, three zones were identified as part of the analysis, each zone located further from the respective green space, as illustrated in Figure 2. 


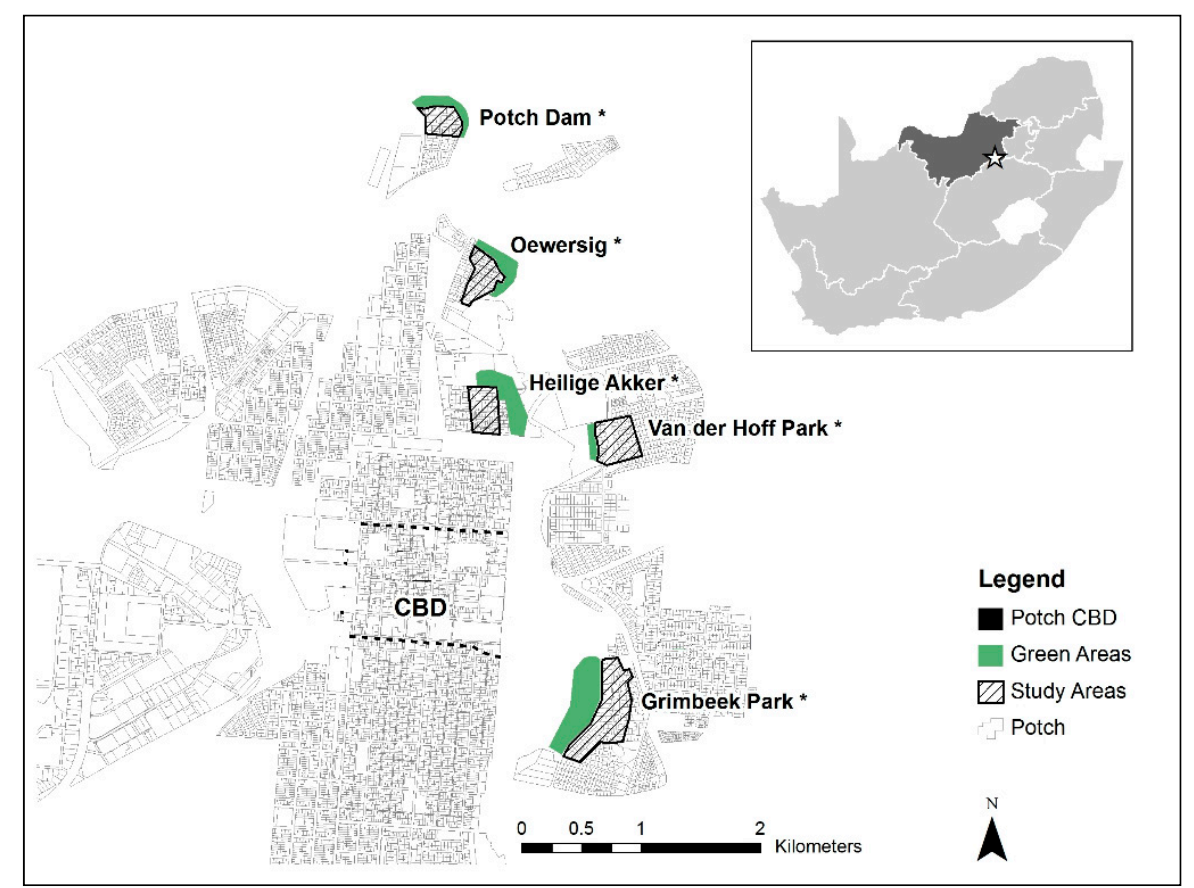

Figure 1. Case study selection to test the proximity principle in Potchefstroom.

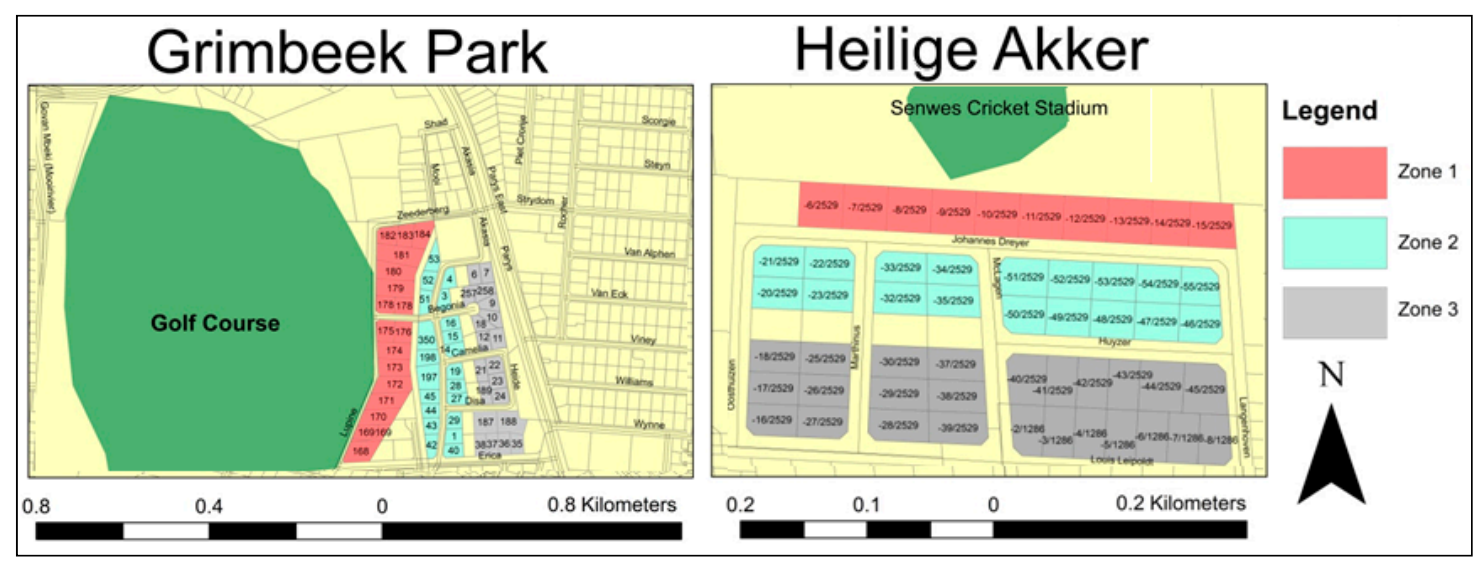

Figure 2. Example of case study selection to test the proximity principle in Potchefstroom.

Analysis of variance (ANOVA) was applied [2] to the property values from residential areas to determine if there is a significant difference between the means of the five areas located at different distances from an urban green space. Kruskal-Wallis analysis was also conducted to determine the significant differences between the groups (zones) of the selected areas and verify results of the ANOVA analysis. The null hypothesis assumed that all areas should have the same property value irrespective of their distances from the green space. Significant differences would reject the hypothesis. In all five areas, irrespective of location or accessibility or usage, Zone 1 had a lower price per square meter (based on the property valuation roll) than in comparison to Zone 2. Comparisons between Zone 1 and Zone 3 in terms of the ANOVA effect sizes illustrated a large practical significant difference $(\approx 0.8)$ between the mean, as well as the effect size within three of the five areas (refer to Table 4). All five areas in Zone 1 illustrated also a lower price per square meter than in comparison to Zone 3 . The collective result of the Potchefstroom study $(n=188)$ illustrated a statistical difference between Zone 1 and the zones located further from the green space, thus rejecting the null hypothesis which assumes that all areas should have the same property value irrespective of their distances from the green space. 
Table 4. Statistical analysis ANOVA and Kruskal-Wallis of green space proximity.

\begin{tabular}{|c|c|c|c|c|c|c|c|c|}
\hline \multirow{2}{*}{ Area } & \multirow{2}{*}{ Zone } & \multirow{2}{*}{$N(\mathbf{1 8 8})$} & \multirow{2}{*}{$\mathrm{R} / \mathrm{m}^{2}$} & \multirow{2}{*}{ (SD) } & \multicolumn{2}{|c|}{ Effect Size } & \multirow{2}{*}{$\begin{array}{l}\text { ANOVA } \\
(p<0.05)\end{array}$} & \multirow{2}{*}{$\begin{array}{c}\text { Kruskal Wallis } \\
(p<0.05)\end{array}$} \\
\hline & & & & & 1 with & 2 with & & \\
\hline Area A: & 1 & 14 & 798.20 & 153.97 & & & & \\
\hline Grimbeek & 2 & 14 & 953.12 & 244.06 & $0.63^{b}$ & & 0.022 & 0.005 \\
\hline Park & 3 & 13 & 974.76 & 76.13 & $1.15^{\mathrm{c}}$ & $0.09^{a}$ & & \\
\hline \multirow{3}{*}{$\begin{array}{c}\text { Area B: Vd } \\
\text { Hoff Park }\end{array}$} & 1 & 15 & 938.29 & 177.71 & & & \multirow{3}{*}{0.003} & \multirow{3}{*}{0.010} \\
\hline & 2 & 15 & 1105.07 & 193.00 & $0.86^{c}$ & & & \\
\hline & 3 & 13 & 1202.56 & 216.72 & $1.22^{\mathrm{C}}$ & $0.45^{b}$ & & \\
\hline \multirow{3}{*}{$\begin{array}{c}\text { Area C: Potch } \\
\text { Dam }\end{array}$} & 1 & 9 & 718.97 & 131.06 & & & \multirow{3}{*}{0.130} & \multirow{3}{*}{0.089} \\
\hline & 2 & 9 & 843.41 & 68.49 & $0.95^{c}$ & & & \\
\hline & 3 & 9 & 925.29 & 330.07 & $0.63^{b}$ & $0.25^{\mathrm{a}}$ & & \\
\hline \multirow{3}{*}{$\begin{array}{c}\text { Area D: } \\
\text { Heilige Akker }\end{array}$} & 1 & 10 & 1114.23 & 176.19 & & & \multirow{3}{*}{0.005} & \multirow{3}{*}{0.010} \\
\hline & 2 & 12 & 1413.52 & 257.52 & $1.16^{\mathrm{c}}$ & & & \\
\hline & 3 & 14 & 1238.36 & 152.32 & $0.7^{\mathrm{c}}$ & $0.68^{b}$ & & \\
\hline \multirow{3}{*}{$\begin{array}{l}\text { Area E: } \\
\text { Owersig }\end{array}$} & 1 & 14 & 1079.50 & 190.48 & & & \multirow{3}{*}{0.055} & \multirow{3}{*}{0.061} \\
\hline & 2 & 14 & 1292.09 & 275.04 & $0.77^{\mathrm{c}}$ & & & \\
\hline & 3 & 13 & 1120.30 & 264.15 & $0.09^{c}$ & $0.69^{c}$ & & \\
\hline
\end{tabular}

This case study disproved the proximity principle as green space, in this singular case, did not have a positive effect on property values adjacent to the green space. Although more similar studies are needed within the local context to provide comprehensive results relating to this theory, including effects of different typologies of open green space, as well as considerations such as accessibility and usability, this case study did identify the possibility that the theory might not be applicable to all urban areas, especially in South Africa where safety considerations might be responsible for this deviation of international accepted theory.

Safety was also identified as core consideration in the research conducted in another area in Potchefstroom [48] in the North-West Province of South Africa, where 97.8\% (valid percentage) of the cumulative respondents considered in the case study, identified the need for safer green spaces. Although findings illustrated no statistical significance, it did illustrate a moderate effect and practical visible association relating to installation of fences to enhance security $(\mathrm{V}=0.254, p=0.081)$ and for installing security cameras in the public green space $(\mathrm{V}=0.265, p=0.069)$. The importance of context-based planning was highlighted through these studies. Safety concerns were emphasized as a local challenge impacting on green infrastructure usage and the valuation thereof. Safety in this sense, directly influences the proximity principle of green infrastructure in South Africa. Future research should therefore quantify the value of green infrastructure in Africa, referring to the benefits of green infrastructure, reflected in terms of social, environmental and economic benefits, that might differ significantly from the international norm, due to different contextual challenges and considerations.

\subsection{Findings on Long-Term Planning Strategies for the Local Context}

Long-term strategies relating to green infrastructure entail policy support, but also adequate human capacity to drive the values relating to green infrastructure. A notable observation of the collective studies considered for this paper, was that professionals planning for green infrastructure often drive green infrastructure planning from the notion of intrinsic values (aesthetic services), whereas communities prefer and preference use-values (functional services such as recreation or leisure areas). A community survey [49] conducted in Klerksdorp, North-West Province, compared the perceptions of 20 local community members against that of 10 planning professionals who all interacted in the same space.

A comparative group analysis was conducted to determine if communities and professionals has a similar perspective on green spaces, or whether these groups value specific urban green typologies differently. The respondents were requested to rank the importance of the bicycle lanes, recycling 
opportunities, rain gardens, green walls, green roofs, pedestrian friendly streets, urban agriculture, green public open spaces, and street trees within the urban landscape. The comparative analysis considered the collective group response as a percentage of the total number of responses received, as evident in Figure 3.

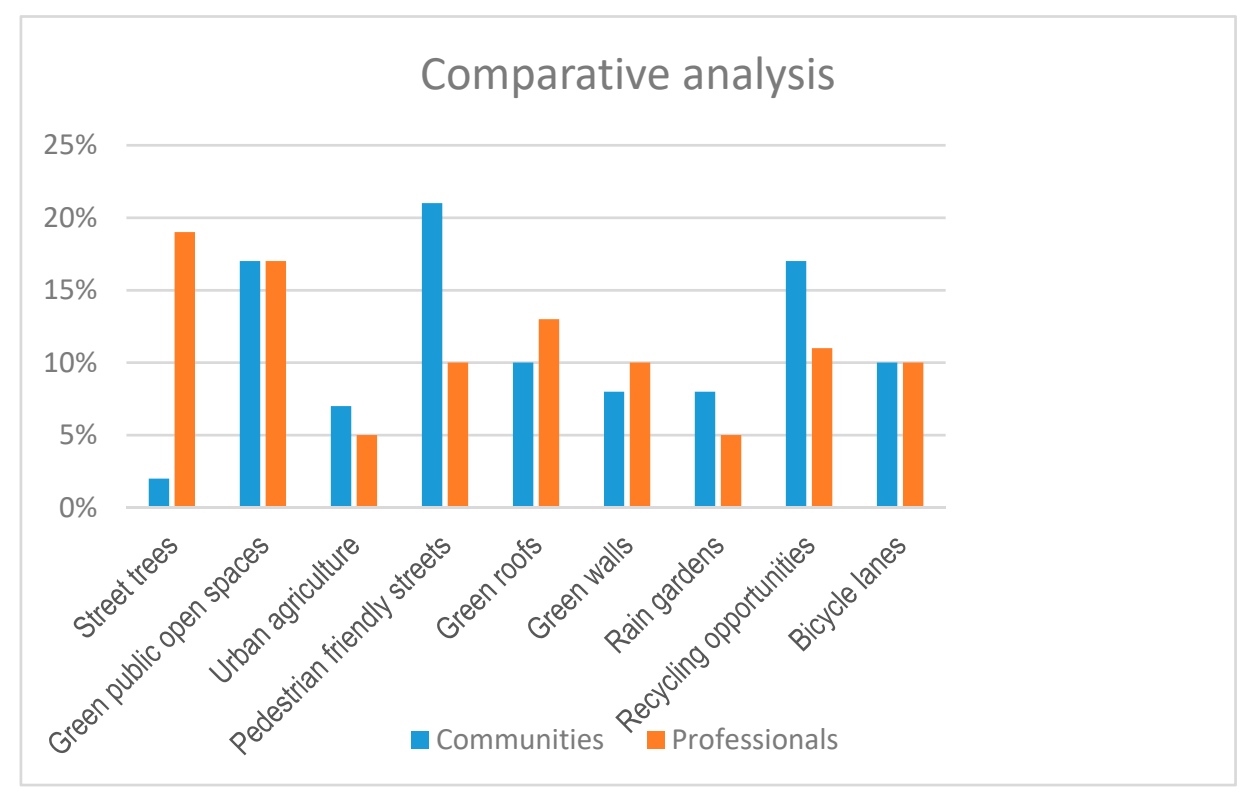

Figure 3. Comparative analysis of community versus professional perspectives of green spaces.

The comparative analysis between the community perspective and professional perspective pertaining to green spaces, are emphasized by the stacked bar chart (Figure 4) which uses the length of the two stacked bars (community and professionals) to represent the components of a total quantitative value, and in this case, identify the preference per specific typology. From Figure 4, it is evident that professional's place preference on design-orientated green infrastructure (green walls, green roofs, street trees) which would ultimately improve aesthetics values, in comparison to the community preference towards green space usage (rain gardens for domestic use, pedestrian-friendly spaces, urban agriculture for domestic benefits), as illustrated in the Figure 4. Bicycle lanes and green public open spaces were equally valued by both the professionals and the communities and did not pose any significant findings for this research.

Similar research conducted in Potchefstroom [48] in the North-West Province of South Africa, considered different cultures of communities and their viewpoint relating to green space usage. Although data was not found to be statistically significant $(p=0.094), 93 \%$ of the collective group of stakeholders considered recreational activities to be an important function of the green space. Almost all (97.8\% valid percentage) of the cumulative respondents identified the need for safer environments. Similar results were evident in the in the Fleurhof case study [42] which was, according to professionals, planned to be an integrated neighborhood with adequate green spaces and supporting green infrastructure. In total, $82 \%$ of community members included in the study agreed that the planned green spaces in the area were indeed "recreational open spaces", but ironically only $35 \%$ of the respondents indicated to use these spaces more than once per year. Community members indicated that the green spaces, although planned as recreational open spaces, did not meet their needs with regard to adequate facilities or infrastructure. The case study illustrated the need for functional green spaces, and provision of qualitative green spaces that is well equipped and maintained. Again, such occurrence can revert back to inadequate planning for green infrastructure, due to a lack of understanding of the importance and role of green infrastructure, which ultimately then results in green spaces with no function or use-value. 


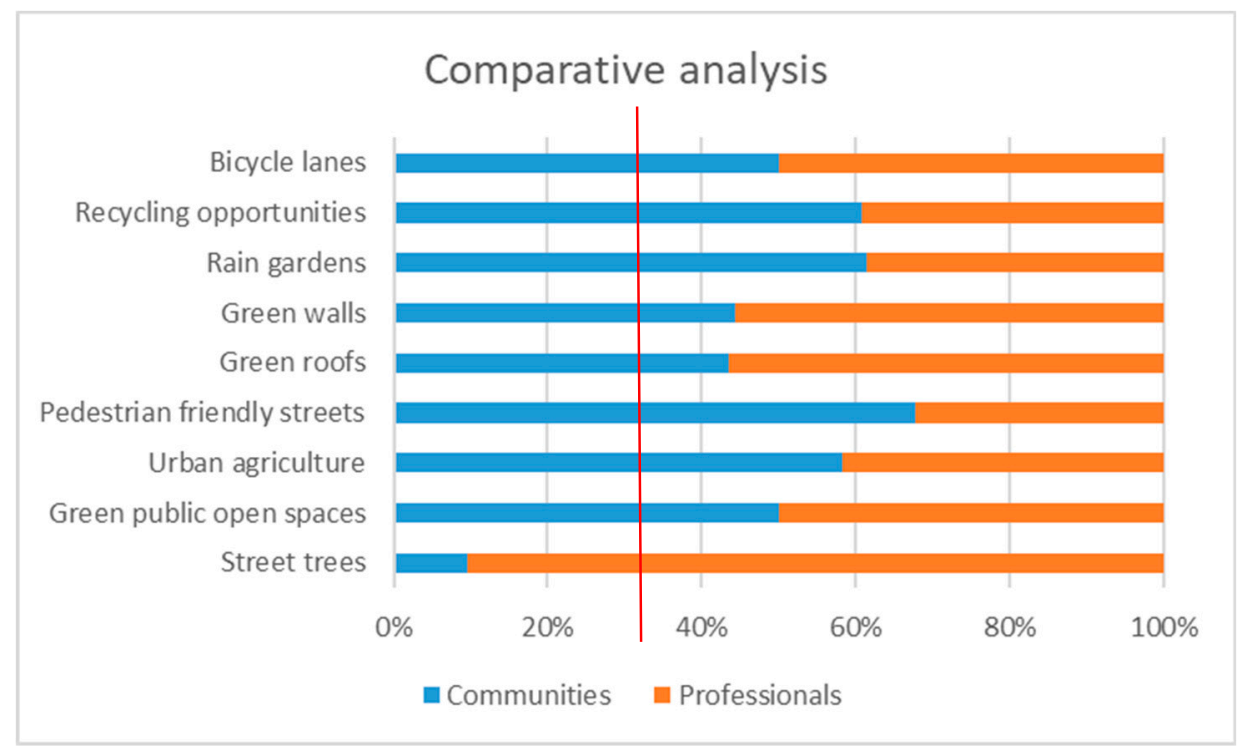

Figure 4. Stack bar comparison of community versus professional perspectives.

Part of the problem with planning and providing successful green infrastructure, especially in South Africa, might be that spatial planners are not adequately educated regarding the scope, importance and role of green infrastructure as part of broader spatial planning approaches. The research [38] suggested that green infrastructure is not comprehensively included in urban and regional tertiary education, as $46 \%$ of professional planners included in the research stated that they had no formal education on green infrastructure. All participants indicated the need to improve tertiary education in this sense, as well as disseminating results and knowledge of green infrastructure to practicing planners, to bridge the current practice-gap.

A survey conducted in 2017 amongst a convenience sample of urban planners, project managers, and engineers also illustrated similar results [39]. Purposive sampling was employed whereby participants were included based on their expertise and experience relating to green infrastructure planning. The survey was not focused on proportionality, but on expertise and professional opinion and therefore limited to a small survey sample. The research aimed to consider project management of green infrastructure related projects, investigating the role distribution within project teams and identifying the stakeholders accountable for planning green infrastructure in such multi-disciplinary projects. In total, $60 \%$ of respondents had been in practice for more than 16 years and they illustrated to have good knowledge and good experience (93.3\%) of project management, as well as good knowledge $(80 \%)$ and good experience $(86.7 \%)$ of green infrastructure. All of the respondents identified the lack of knowledge of the benefits of green infrastructure as main reason for the lack of green infrastructure implementation in practice. Most respondents illustrated that they would predominantly endorse green infrastructure within a project to limit the costs of implementation $(86 \%)$, as well as address the green agenda $(47 \%)$. The minority considered the savings in terms of implementation costs $(27 \%)$ and maintenance costs (47\%) as good reasons to promote green infrastructure. All of the respondents illustrated the need to extent their knowledge relating to the management of green space projects.

The Fleurhof case study [42] illustrated a similar trend applicable to education from the viewpoint of community members. $87 \%$ of community members included in the case study illustrated the need to learn more about environmental planning practices, correlating to the number of participants who considered environmental planning to be important (with a practical significant association and effect size of 0.501). From the respective studies it was evident that both local communities and experts do not comprehend the scope, value, and importance of green infrastructure and that extreme attempts should be made to revise education approaches. Green infrastructure and the transdisciplinary planning thereof should be prioritized in spatial planning education, to ensure that the myriad of professionals 
included in the spatial planning process, understand the scope and benefits of green infrastructure planning, to inform long-term strategies from a sustainable point of departure.

\section{Conclusions}

Green infrastructure poses a probable solution towards sustainable spatial planning. In the African context, two schools of thought are robustly negotiated, considering conservation of nature on the one hand, and urban development for growth on the other. Although much has been accomplished over the last couple of years in terms of green infrastructure development, the concept of green infrastructure is still limited and undervalued within broader spatial planning approaches in Africa, especially in South Africa. Based on the research presented in this paper, conclusions were drawn with respect to the local interpretation of the green infrastructure concept, functionality, benefits, and long-term strategies, as captured in Table 5.

Table 5. Thematic research findings.

\begin{tabular}{ccc}
\hline Principles & Research Presented in This Paper & Findings \\
Concept & $\begin{array}{c}\text { Misconceptions of Green } \\
\text { Infrastructure [38,42,50] } \\
\text { Needs relating to Green } \\
\text { Infrastructure [41,50] }\end{array}$ & $\begin{array}{c}\text { Define concept in African context } \\
\text { Sensitize beneficiaries }\end{array}$ \\
\hline Functionality & $\begin{array}{c}\text { Green compensation } \\
\text { principle [31,48] }\end{array}$ & Context-based planning \\
\hline Benefits & Proximity principle [2] & Value capturing \\
\hline \multirow{2}{*}{ Long-term planning strategies } & Green drivers [48-50] & Green Infrastructure as spatial issue \\
& Green education [38,39]
\end{tabular}

The findings as presented in Table 5 are discussed accordingly, along with planning recommendations to strengthen green infrastructure within the local context, to enhance functionality through context-based planning, to employ value-capturing to contextualize green infrastructure benefits and ultimately to structure long-term planning strategies that consider green infrastructure as an integral spatial issue.

\subsection{Define and Interpret Green Infrastructure in Local Context}

Although much has been accomplished over the last decade, South Africa, similar to most of Africa, still lacks a uniform definition for green infrastructure. As a result, stakeholders and communities does not fully comprehend the value and benefits relating to green infrastructure and therefore green infrastructure is often not prioritized in land use decision-making. Deliberate efforts should be made to define green infrastructure and capture the values of green infrastructure in an African context (departing from the hypothesis that planning in Africa cannot be a blue-print from international cases). The value and benefits of green infrastructure should be quantified and related to beneficiaries (health benefits and increased property values for instance are more important for communities, but greater marketability and neighborhood value and taxes are more important to sensitize authorities). Methods, theories, and equations of urban economics and green economics should be translated into African planning approaches which can guide evidence-based decision making. Unique context-based challenges should be taken into considerations, such as safety concerns, which was proven to have an effect on the proximity principle (economic valuation of green infrastructure) and the compensation hypothesis (social valuation of green infrastructure). More research is needed to sustain the results obtained from these case studies and to define and valuate green infrastructure in broader African context. Such valuation methods might also raise awareness and sensitize planners, policy makers and also the general public to realize the value and potential of green infrastructure and encourage city governments to embed sustainability thinking 
into city planning. Provided that the value-capturing information is packaged appropriately, these numbers can also strengthen the case for environmentally beneficial legislation to further enhance green infrastructure planning, and position the concept of green infrastructure in Africa as an integral part of the infrastructural fabric that supports and sustains society.

\subsection{Enhance Functionality through Context-Based Planning}

Context-based planning lies central to the successful implementation of green infrastructure and should firstly be supported by adequate policies and legislative frameworks in aid of green infrastructure planning. The vivid contrasts between the Global North and Global South should be acknowledged in this regard, relating to the conditions that guide urban planning, personified by ethnically divided societies, poor infrastructure, poverty, political instability, weak public institutions, vast informal sectors, and associations between the modern and defiantly traditional. This research identified 'safety' and 'culture' as primary denominators impacting on the concept of green infrastructure planning in Africa as results probe that different communities (cultures) use spaces differently depending on their valuation of the green space and function connected thereto, and that most Africans included in this research do not value green spaces due to the safety concerns related to such spaces. In this sense, the compensation hypothesis was contradicted (implying local communities would not compensate to increase accessibility to green spaces, suggesting of the undervaluation of green infrastructure from a local perspective), and the green proximity principle was disproved within the singular case studies conducted in South Africa (again suggesting of the undervaluation of green spaces from an economic perspective in local context). The results called for context-based planning, where more and similar research should be conducted to enhance the trustworthiness and draw informed conclusions, especially when considering other impacts such as green space typologies, accessibility, and use-values. This research confirms that, similar to the broad literature on green infrastructure, the principles of accessibility, connectivity, and scale of green infrastructure are important considerations to ensure the successful implementation and utilization of green infrastructure in African context, but that green infrastructure should be planned according to (community) use-values to enhance the context and significance thereof within the African environment. However, it is within these guiding principles that context-based planning should be prioritized, to address actual community needs, and to shift green infrastructure from a luxury good to a necessity for social wellbeing.

\subsection{Contextualise Green Infrastructure Benefits through Value-Capturing}

The most secure way to position green infrastructure in the South African context as an integral part of decision-making and land use management, is to clearly identify the multiple benefits and direct and indirect values of such green infrastructure, for both communities and authorities. The importance of multi-functionality, as principle of green infrastructure, is undervalued within the local context. As such, societies are fast to compensate green spaces, because they do not grasp the importance and role of such green infrastructure. On the other hand, decision-making authorities do not provide adequate and quality green infrastructure, because of various misconceptions relating to the concept and importance thereof, budget constraints, and development priorities. As such, green infrastructure should be valued and quantified in terms of the broader social, environmental, and economic benefits that it can provide to communities and authorities in African context. It is these multiple benefits of green infrastructure are adequately captured, it can inform evidence-based decision making. This paper illustrated contradictions to the global theories relating to the valuation of green infrastructure, which could be used as point of departure for more similar research initiatives. The evidence-base of the value of green infrastructure in African context needs to be expanded through multiple case studies across Africa. The value should be captured and linked to beneficiaries (communities and authorities) to contextualize the green infrastructure benefits and convince communities and authorities about the necessity to integrate green infrastructure in all facets of the sustainable development discussions. 


\subsection{Structure Long-Term Planning Strategies that Consider Green Infrastructure as Integral Spatial Issue}

There is an increasing awareness among policymakers in Africa that Green Infrastructure is a core dominator towards realizing sustainable development objectives. The gap between policy and practice is however evident in the South African context where much focused is still placed on traditional infrastructure. Green infrastructure is not yet integrated into spatial planning thinking and practitioners are yet to grasp that green infrastructure can deliver similar goods and services, but with multiple benefits, when planned as an integral part of a city's infrastructure. Long-term strategies call upon the realization of a green network, not approached as ad hoc urban greening projects which is often considered the currently reality in African context. The need for redundancy and diversity should be well explored within the concept of green infrastructure in African context. Green infrastructure should be well understood by the myriad of professionals linked to the planning process, to ensure successful planning and implementation thereof over the long-term. The generation of knowledge should be supported by transdisciplinary thinking and interdisciplinary collaboration on green infrastructure planning. The misinterpretation of concepts (as with the valuation and appreciation thereof), referred to as the 'value gap' [50] should be addressed through adequate education, training, and professional development initiatives. Concepts such as green infrastructure, ecosystem services and disservices, resilience, sustainability and transdisciplinary planning should form part of the common language of the future spatial planners. The planning literature base should be expanded to include the value of green infrastructure in the broader African context, along with the application of sound scientific knowledge to set a standard for the responsible use of natural resources and the sufficient planning of green infrastructure, to ultimately enhance sustainable cities and regions in Africa.

\section{Summary on the (South) African Contribution to the Academic Discourse on Green Infrastructure}

The (South) African context and spatial landscape with its socio-economic issues and strained social contexts struggle to emulate to Western models of green infrastructure planning, mainly due to misunderstanding or undervaluation of the benefits associated to such infrastructure and the importance of including green infrastructure as part of mainstream spatial planning. Although the importance and valuable role of green infrastructure within the African landscape is not questioned, the reluctance of African countries to introduce green infrastructure does provide a valuable opportunity to consider the notion of green infrastructure and context-based planning, the translation of Global North theories to the Global South contexts, and the identification of perception factors that play a part in the successful optimization and implementation of green infrastructure in African cities. The African approach to, or rather lack of green infrastructure planning, contributes to the academic discourse on the valuation of green spaces and perceptions regarding green infrastructure by illustrating the contradicting findings relating to the proximity principle and compensation principles, evident in the undervaluation and malfunctioning of such spaces in African context. Even though the social, economic, and ecological benefits of green infrastructure can spin off in numerous opportunities and improved living conditions for (South) African communities, much effort is needed to change perceptions, to sensitize decision-makers, to understand that green spaces are not a luxury good but an essential to sustainable living for both urban and rural contexts, to redesign public spaces according to safety principles, to understand user-values and valuation, and to reflect these context-specific needs and challenges in long term planning strategies and opportunities to strengthen green infrastructure provision in South Africa and Africa.

Funding: The financial assistance of the National Research Foundation (NRF) towards this research is hereby acknowledged.

Disclaimer: Opinions expressed, and conclusions arrived at, are those of the authors and are not necessarily to be attributed to the NRF. 
Conflicts of Interest: The author declares no conflict of interest.

\section{References}

1. Sustainable Cities Institute. Land Use. The National League of Cities. 2012. Available online: http:/ / www.sustainablecitiesinstitute.org/Documents/SCI/Topic_Overviews/Land\%20Use\%20\%20Full\%20OverviewNew_NLC.pdf (accessed on 22 March 2016).

2. Cilliers, E.J.; Cilliers, S.S. From green to gold: A South African example of valuing urban green spaces in some residential areas in Potchefstroom. Town Plan. Rev. 2015, 67, 1-12.

3. United Nations. Progress Towards the Sustainable Development Goals. Report to the Secretary-General. E/2017/66. 2017. Available online: http:/ /www.un.org/ga/search/view_doc.asp?symbol=E/2017/66\& Lang=E (accessed on 5 July 2017).

4. Anderson, P.; Elmqvist, T. Urban Ecological and Social-Ecological Research in the City of Cape Town: Insights Emerging from an Urban Ecology CityLab. Ecol. Soc. 2012, 17, 269-273. [CrossRef]

5. Llausàs, A.; Roe, M. Green Infrastructure planning: Cross-national analysis between the North East of England (UK) and Catalonia (Spain). Eur. Plan. Stud. 2012, 20, 641-663. [CrossRef]

6. Thomas, K.; Littlewood, S. From green belts to green infrastructure? The evolution of a new concept in the emerging soft governance of spatial strategies. Plan. Pract. Res. 2010, 25, 203-222. [CrossRef]

7. Wright, H. Understanding green infrastructure: The development of a contested concept in England. Local Environ. 2011, 16, 1003-1019. [CrossRef]

8. Forman, T.T. Ecological resilience as a foundation for urban design and sustainability. In Resilience in Ecology and Urban Design; Pickett, S.T.A., Cadenasso, M.L., McGrath, B., Eds.; Springer: Dordrecht, The Netherlands, 2013.

9. Liu, Z.; Mao, F.; Zhou, W.; Li, Q.; Haung, J.; Zhu, X. Accessibility Assessment of Urban Green Space: A Quantitative Perspective; School of Architecture, Tsinghua University: Beijing, China, 2007.

10. Stigsdotter, U.A. Urban Green Spaces: Promoting Health through City Planning; Swedish University of Agricultural Sciences: Uppsala, Sweden, 2008; 17p.

11. Niemelä, J.; Saarela, S.R.; Söderman, T.; Kopperoinen, L.; Yli-Pelkonen, V.; Väre, S.; Kotze, D.J. Using the ecosystem approach for better planning and conservation of urban green spaces: A Finland case study. Biodivers. Conserv. 2010, 19, 3225-3243. [CrossRef]

12. Landscape Institute. Green Infrastructure: An Integrated Approach to Land Use. London. 2013. Available online: http:/ / www.landscapeinstitute.org/PDF/Contribute/2013GreenInfrastructureLIPositionStatement. pdf (accessed on 22 March 2016).

13. Ahern, J. From fail-safe to safe-to-fail: Sustainability and resilience in the new urban world. Landsc. Urban Plan. 2011, 100, 341-343. [CrossRef]

14. Davies, C.; McGloin, C.; MacFarlane, R.; Roe, M. Green Infrastructure Planning Guide Project: Final Report; NECE: Annfield Plain, UK, 2006.

15. Ahern, J. Green infrastructure for cities: The spatial dimension. In Cities of the Future towards Integrated Sustainable Water and Landscape Management; Novotny, V., Brown, P., Eds.; IWA Publishing: London, UK, 2007; pp. 267-283.

16. Mell, C. Green Infrastructure: Concepts and planning. Forum E J. 2008, 8, 69-80.

17. Benedict, M.A.; McMahon, E.D. Green Infrastructure: Linking Landscapes and Communities; Island Press: Washington, DC, USA, 2006.

18. Harrison, P.; Bobbins, K.; Culwick, C.; Humby, T.; La Mantia, C.; Todes, A.; Weakley, D. Resilience Thinking for Municipalities; University of the Witwatersrand, Gauteng City-Region Observatory: Johannesburg, South Africa, 2014.

19. Colding, J. The role of ecosystem services in contemporary urban planning. In Urban Ecology: Patterns, Processes and Applications; Niemelä, J., Breuste, J.H., Elmqvist, T., Guntenspergen, G., James, P., McIntyre, N., Eds.; Oxford University Press: New York, NY, USA, 2011; pp. 228-237.

20. Young, R.; Zanders, J.; Lieberknecht, K.; Fassman-Beck, E. A comprehensive typology for mainstreaming urban green infrastructure. J. Hydrol. 2014, 519, 2571-2583. [CrossRef]

21. Rics. The Value of Sustainability: Meeting of the Minds, Asset Strategies. 2006. Available online: www.rics. org/site/scripts/press_article.aspx?pressreleaseID=117 (accessed on 10 June 2016). 
22. Dobbs, C.; Escobedo, F.J.; Zipperer, W.C. A framework for developing urban forest ecosystem services and goods indicators. Landsc. Urban Plan. 2011, 99, 196-206. [CrossRef]

23. James, P.; Tzoulas, K.; Adams, M.D.; Annett, P.; Barber, A.; Box, J. Towards an integrated understanding of green space in the European built environment. Urban For. Urban Green. 2009, 8, 65-75. [CrossRef]

24. Soares, A.L.; Rego, F.C.; McPherson, E.G.; Simpson, J.R.; Peper, P.J.; Xiao, Q. Benefits and costs of street trees in Lisbon, Portugal. Urban For. Urban Green. 2011, 10, 69-78. [CrossRef]

25. Van Leeuwen, E.; Nijkamp, P.; de Norohna Vaz, T. The multi-functional use of urban green space. Int. J. Agric. Sustain. 2010, 8, 1-13. [CrossRef]

26. Cilliers, E.J.; Cilliers, S.S. Planning for Green Infrastructure: Options for South African Cities; South African Cities Network: Johannesburg, South Africa, 2016; 56p, ISBN 978-0-620-72315-2.

27. Brasington, D.M.; Hite, D. Demand for environmental quality: A spatial hedonic analysis. Reg. Sci. Urban Econ. 2005, 35, 57-82. [CrossRef]

28. Irwin, E.G. The Effects of Open Space on Residential Property Values. Land Econ. 2002, 78, 465-480. [CrossRef]

29. Turner, M.A. Landscape Preferences and Patterns of Residential Development. J. Urban Econ. 2005, 57, 19-54. [CrossRef]

30. Goffette-Nagot, F.; Reginster, I.; Thomas, I. Spatial analysis of residential land prices in Belgium: accessibility, linguistic border, and environmental amenities. Reg. Stud. 2010, 45, 1253-1268. [CrossRef]

31. Lategan, L.G.; Cilliers, E.J. Considering urban green space and informal backyard rentals in South Africa: Disproving the compensation hypothesis. Town Reg. Plan. 2016, 69, 1-18. [CrossRef]

32. Countryside Agency \& Groundwork. The Countryside in and Around Towns: A Vision for Connecting Town and Country in the Pursuit of Sustainable Development; The Countryside Agency: Wetherby, UK, 2005.

33. Gallent, N.; Anderson, J.; Bianconi, M.; Osment, F. Vision for a sustainable, multi-functional rural-urban fringe. In Bartlett School of Planning and LDA Design; Final Report; The Countryside Agency: London, UK, 2004.

34. Benedict, M.A.; McMahon, E.D. Green Infrastructure: Smart Conservation for the 21st Century. Reneww. Resour. J. Autumn Ed. 2002, 12-17.

35. TEP. Advancing the Delivery of Green Infrastructure: Targeting Issues in England's Northwest; The Environment Partnership: Leeds, UK, 2005.

36. Cornelius, G.S.; Viviers, J.; Cilliers, E.J.; Niesing, C. Considering complexities in unique African planning approaches: Abstracting the role of African Urban Residents. WIT Trans. Ecol. Environ. 2017, 223, 415-426.

37. Ellis, S.M.; Steyn, H.S. Practical significance (effect sizes) versus or in combination with statistical significance ( $p$-values). Manag. Dyn. 2013, 12, 51-53.

38. Huston, G.D. Evaluating Local Green Infrastructure Training and Education Approaches within Urban Planning Curricula. Research for the Partial Fulfilment of the Degree B.Art et Scien (Planning); North-West University: Potchefstroom, South Africa, 2016.

39. Thysse, A. Whose Role is It Anyway: Considering Project Management and Green Infrastructure Planning. Research for the Partial Fulfilment of the Degree B.Art et Scien (Planning); North-West University: Potchefstroom, South Africa, 2017.

40. Kuruneri-Chitepo, C.; Shackleton, C.M. The distribution, abundance and composition of street trees in selected towns of the Eastern Cape, South Africa. Urban For. Urban Green 2011, 10, 247-254. [CrossRef]

41. Gibbens, C.M.; Cilliers, E.J. Playing for keeps: How integral are child-friendly spaces to communities in rural areas, with reference to Griekwastad as a case study. Under review.

42. Veiga, R. A Proposed Green Planning Development Framework: Integration of Spatial Planning and Green Infrastructure Planning. Research for the Partial Fulfilment of the Degree M.Art et Scien (Master degree Planning); North-West University: Potchefstroom, South Africa, 2015.

43. Municipality, J.M. City of Johannesburg. In Consolidated Johannesburg Town Planning Scheme; City of Johannesburg: Johannesburg, South Africa, 2011.

44. Maat, K.; de Vries, P. The influence of the residential environment on greenspace travel: Testing the compensation hypothesis. Environ. Plan. A 2006, 38, 2111-2127. [CrossRef]

45. Lin, B.; Meyers, J.; Barnett, G. Understanding the potential loss and inequities of green space distribution with urban densification. Urban For. Urban Green. 2015, 14, 952-958. [CrossRef] 
46. Westen. Oudtshoorn Local Municipality [personal interview with Dr Louis Lategan, PhD Urban and Regional Planning, North-West University, South Africa]. 14 August 2013.

47. Cilliers, S.S.; Cilliers, E.J.; Lubbe, C.E.; Siebert, S.J. Ecosystem services of urban green spaces in African countries-Perspectives and challenges. Urban Ecosyst. 2013, 16, 681-702. [CrossRef]

48. Louw, J.C. Perceptions of Undesirable Structural Elements in Open Urban Spaces. Research for the Partial Fulfilment of the Degree B.Art et Scien (Planning); North-West University: Potchefstroom, South African, 2017.

49. Jacobs, N.S. The Regeneration of Klerksdorp's CBD: A Greening Approach. Research for the Partial Fulfilment of the Degree B.Art et Scien (Planning); North-West University: Potchefstroom, South Africa, 2016.

50. Cilliers, E.J. Bridging the green-value-gap: A South African approach. Int. J. Environ. Chem. Ecol. Geol. Geophys. Eng. 2009, 3, 182-187.

(C) 2019 by the author. Licensee MDPI, Basel, Switzerland. This article is an open access article distributed under the terms and conditions of the Creative Commons Attribution (CC BY) license (http:/ / creativecommons.org/licenses/by/4.0/). 